\title{
READERS
Insight
}

Journal of Management Info (JMI)

ISSN:2313-3376

www.readersinsight.net/jmi

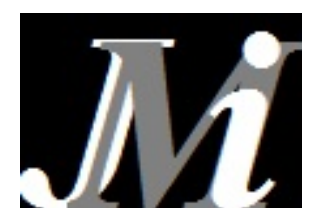

\section{Quadruple culture type approaches impacting employees attributes}

\author{
Muhammad Shafiq ${ }^{1}$, Muhammad Imran Qureshi² \\ ${ }^{1}$ COMSATS Institute of Information Technology, Wah, Pakistan \\ ${ }^{2}$ Universiti Teknologi Malaysia \\ * Corresponding author: miqureshi80@gmail.com
}

\begin{abstract}
The study examines the relationship among organizational culture, employee performance, employee satisfaction and turnover in the telecommunication sector of Pakistan. Empirical studies are needed to understand the phenomena, so that the organizations would be able to handle the barriers in management objectives. It was a field study so survey was formed and conducted; data was gathered through distributed questionnaires from 260 employees of public \& private, national and multinationals organizations from the cities of Rawalpindi-Islamabad. All the employees willingly participated in the survey though their confidentiality was in tacked. Interestingly the results of this specific investigation make this study unique and important as it indicated that organizational culture types Community, Innovative, Competitive and Bureaucratic on employee performance, satisfaction and turnover have different impacts. The study relies on cross-sectional data obtained once from employees of multiple multinationals and national organizations. The employees were from all three types of organizations i.e. service providers, contractors and sub-contractors. Regression tests were applied to analyze the data. . It leads to conclusion that employees are performing well, even being unsatisfied and want to remain with their current jobs. This study provides the knowledge that the results of the measures of same constructs cannot be same across different cultures and countries. With this study government and managers should realize the alarming situation in their organizations regarding employees' behaviors in sometimes unfeasible organizational cultures. The future studies should examine the political and economic constructs and their influence on organizational culture and employees. The present study wishes to contribute in the knowledge gap regarding how organizational culture is impacting employees' performance, satisfaction and turnover in telecommunication sector of Pakistan It also raises the importance for exploring and developing the theories on the basis of economic and political aspects rather perceiving single theory equally across different cultures.
\end{abstract}

\section{ARTICLE INFORMATION}

$\begin{array}{ll}\text { Received: } & 25 \text { March } 2014 \\ \text { Revised: } & 25 \text { May } 2014\end{array}$

Accepted: 25 June 2014

DOI:

http://dx.doi.org// 10.31580/jmi.v2i1.3

\section{Introduction}

Organizations are becoming more culturally diverse, mainly because of their operations globally. Organization culture is an old concept (Cartwright \& Cooper 1990). All employees of an organization sharing conventional stuff make culture. New entrants in organizations should adopt this stuff as well(Jacques 1951). FosterFishman and Keys (1997) proposed that direction of the team members behavior is developed by collective method of understanding that is called organizational culture. Deshpande and Webster (1989) present that individuals recognize organizational working and behavior with the help of the blueprint of common principles and attitudes in the organization. The overall attributes of employees are impacted by culture (Song et al, 2009). Organizational culture and its relation with employee's performance, job satisfaction and other attributes have always been a very important area of research (Emmanuel \& Lloyd 2000, Habib et al, 2011). Studies show that organizational culture impacts the employee's performance, satisfaction and turnover (Jae San and Tae Hyun 2009, Macintosh and Doherty 2010). Jennifer \&Jehn (1994) described that different organizations have different organizational cultures. Values, actions and behaviors make the organizational culture while employees of the organization share and follow it (Saeed et al, 2010).

It is proven in management research that organizational culture relates to many employee and organizational outcomes (Sheridan 1992; Tsui et al 2011; Denison and Mishra 1995). Studies refer that loyalty; improved performance and low turnoverare some of employees attribute which are results of organizational understanding of employees (Annelies E. M Van Vianen). Employees' perception of the organizational culture influences the turnover (Sheridan 1992), moreover, determinants of individual and collective organizational turnover, both have been researched in the past (Huselid 1995). Satisfaction and performance out comes are affected by the organizational culture (Lund, 2003; Zhang \& Zheng, 2009). Jennifer \&Jehn (1994) also presented that organizational cultures of an industry can be same at the same location. Telecommunications has been one of the most developed sectors in Pakistan over the last 7 years. Employees are the most important part of the organization and their behaviors significantly improve the organizational objectives. This study will focus on exploring the organizational culture of this expanding industry, and its impacts on employee's behaviors. 
This area of organizational theory has become one of the most significant concepts for researchers to figure out due to the efforts of the mentioned striking works and others (Alvesson, 2002). Despite lot of research, due to cultural divergence in different countries, the managers and leaders must understand their employees and values (Gentry \& Sparks, 2011). Pakistan has an economy of \$233 billion. $53 \%$ of the economy is from service sector. $37 \%$ of the labor force is from the service sector. Telecommunication is the among the most important service industries of the country, contributing 3\% in overall economy. It contributes PRS117 billion in revenue of the country (Pakistan Revenue Board). $71.6 \%$ of the population uses the landline and mobile services, representing a very high tele-density (PTA). There are approximately 60000 people, employed by the telecommunication organizations; 12000 of those work in the twin cities of Rawalpindi and Islamabad (HR PTA, HR PTCL). The huge industry of telecommunication is facing a lot of employee issues which need to be addressed. The cultural prospect has to be analyzed in the local context (Gentry \& Sparks, 2011). As signified by Zhou \& $\mathrm{Su}$ (2010) that different cultures have different sensitivities and output; so we have to explore it in our country's prospect as well. This study will focus to explore the Impacts of Organizational culture in the telecom sector of Pakistan, monitoring the employee's behaviors in their performance, satisfaction and turnover. Work environment can be improved with knowledge of the role of the organizational culture as predictor of satisfaction, performance and turnover in telecommunication industry.

The intent of this study is to explore the construct of organizational culture, its dimensions and types in telecom sector of Pakistan and their impacts on employee's outcomes. The employees' outcomes of satisfaction, performance and turnover are analyzed in this study. The questions needed to be explored and presented in this thesis are;

1. What are the existing organizational cultures telecommunication sector in Pakistan?

2. What are the impacts of organizational culture on employee's performance, satisfaction and turnover?

3. Which of the culture is significant for employees in the telecommunication sector of Pakistan?

The concept that organizational culture impacts many employee and organizational outcomes is proven in the research (Sheridan 1992; Tsui et al 2011; Denison and Mishra 1995). Lund (2003) also proposed that organizational culture influences satisfaction, commitment and performance.There is a great requirement for research on organizational culture types and on employee's attributes (Lund, 2003). Zhang \&Zheng (2009) presented that employee's behaviors are influenced by culture. There has not been much research in Pakistan telecommunication sector about the organizational culture and employee behaviors. Though there has been research about the role of organizational culture, about knowledge management by Saeed et al, (2011). Moreover, the few researches on the employee satisfaction and turnover by (Nazim Ali, 2010), and impact of stress on employee performance by (Bashir and Ramay, 2010). But neither there have been many researches on organizational culture in general in Pakistan, analyzing its outcomes, nor specifically focusing on telecommunication industry. This study is significant in this context to help the grown telecommunication industry in general, and specifically the organizations which are facing a problem of employee loyalty and satisfaction. Moreover, Pakistan facing recession and inflation in slow economy growth and in layoffs, it is important to see the organizational culture impact on employee attributes. In this era of organizations mergers and employee layoffs, this study can be a big leap forward for management and researchers to explore the diverse attributes of organization-employee relationship.

Telecommunication Industry has played a great role to enhance the services sector of the country. Telenor, Warid, Mobilink, Chaina Mobile, Uphone, PTCL, Wateen, are the service providers of international repute. On the other hand, Nokia Siemens Networks, Alcatel-Lucent, Ericsson, Huawei, ZTE are international vendors, serving in Pakistan for years.

The fundamental objective of this research is to:
1. Investigate impact of organizational culture on employee performance, satisfaction and turnover in telecommunication sector of Pakistan.

2. Offer a suggestion to Top management and HR managers about organizational culture, which may support in making strategic agendas.

3. Offering a general support to industry and government.

\section{Organizational culture}

It has always been very interesting for the researchers to explore Organizational culture, and very difficult to determine as Rousseau suggested it controversial to assess culture quantitative (Rousseau 1990). Literature has many arguments about measuring and observing Organizational culture (Marcoulides, Heck 1993). Some authors suggest it as central values of employees and the organization $\left(\mathrm{O}^{\prime}\right.$ Reilly III, Chatman, and Caldwell, 1991), and a central value system of organization related behaviors shared at units and levels in an organization (Weiner, 1988). Saeed et al (2010) proposes that organizational culture bonds the social structure of an organization together.

Schein (1995) referred to the validated solutions of problems flowing in the generations of employees create organizational culture. This pattern of solutions is created due to External focus and internal absorption that is represented by organizational culture. Beliefs, values and basic assumptions that help, guide and coordinate member behavior are also known as organizational culture (Schien 1991, Macintosh and Doherty 2010).

\section{Employee satisfaction}

"Job satisfaction refers to an employee's affective or emotional response to his or her particular job" (Cranny, Smith, \& Stone; 1992). Lock (1976) has also been quoted by (Biswas, 2010) defining job satisfaction as 'a pleasurable or positive emotional state resulting from the appraisal of one's job or job experience. This variable is vital and comprehensively researched in organizational psychology (Locke, 1976). A feeling of an individual towards his job is called job satisfaction (Yiing, Ahmad, 2008). Supposed bond between expectation from the job and what expects from the job at offering is job satisfaction (Locke, 1969).Homans (1961) suggests that subjective characteristics of the organizations also impact satisfaction like the objective characteristics of the organization.

\section{Employee turnover}

One of the consistent problems organization face, is the turnover of the employees in all types of organizations whether large, medium or small (Abbasi\&Hollman, 2000). Across industries, personal turnover is strongly predicted by the employee's behavioral intention to leave (Gregory et al., 2007; Miseung Shim 2010). Thoughts of quitting paves the way for turnover, moreover, employees statements to leave also is a big factor of turnover intent (Jae San and Tae Hyun 2009). Availability of job options and competitive environment stress also result in job turnover (Budhwar et al, 2006). Turnover is costly for organizations as it impacts moral of the employees in the organization as well (Abbasi\&Hollman, 2000). Previous researchers Lee \&Mowday (1987) and Lee (2000) also have discussed that turnover intention is the most critical indicator of turnover. Employees' perception of the organizational culture influences the turnover (Sheridan 1992).

\section{Employee performance}

"Behaviors under the control of an individual that advance the goals of an organization" is the classic definition of performance (Rotundo and Sackett, 2002).Borman\&Motowidlo (1993) proposed thatworkcentered behavior (essential) and backgroundcentered behavior (ethical and extra-role) jointly define job performance. Employer's efforts to understand the attitudes and behaviors of employees help to improve employee's performance in growing economies (Soumendu and Arup 2007).Performance is more than job description, to better overall efficiency, organizations require more than the routine responsibilities (Smith et al 1983). Core task 
behaviors, representing formal job responsibilities and organization citizenship behaviors, representing informal extra job role responsibilities, are the two modified measures to identify and measure performance (Stefanie, Courtney and Miguel, 2009).

\section{Literature review}

As society is evolving, culture itself is difficult to comprehend (Mackenzie, 1986). There have always been efforts to develop theory or model to measure the organizational culture and its effectiveness as Denison and Mishra (1995). Treating culture as a solitary entity decreases its importance and wide perspective (Pettigrew, 1979; Martin, 1992; Ogbonna and Harris, 2000).

\section{Organizational culture}

As mentioned above, organization culture is an old concept (Cartwright \& Cooper 1990). All employees of an organization sharing conventional stuff make culture while new entrants should adopt this culture as well (Jacques 1951). Direction of the team members behavior is developed by collective method of understanding that is called organizational culture (Foster-Fishman and Keys, 1997). Organizational culture is also considered as a form of organizational capital (Saeed et al, 2010), making it very important in the overall context of an organization.

Organizations growth to the global level also increase cultural diversity, moreover the domestic diversity of any organization, with multiple ethnic groups also increases the diversity of any organizational culture (Stone et al, 2007).

Organizational culture and its relation with employee's performance, job satisfaction and other attributes have always been a very important area of research (Emmanuel \& Lloyd 2000, Habib et al, 2011). Studies show that organizational culture impacts the employee's performance, satisfaction and turnover (Jae San and Tae Hyun 2009, Macintosh and Doherty 2010). Jennifer \&Jehn (1994) described that different organizations have different organizational cultures. Biswas (2010) also presents many researches from past (Parker et al; 2003; Woodard, Cassill\& Herr, 1994) showing the organizational climate factoring impacting the turnover and job satisfaction.

There has always been many efforts to develop a central theory to organizational culture from 1940s (Chapple) and 1950s(Jacques, Dalton and Roy) through 1970s (Clark and Turner) till Schein (1985) as discussed in detail by (Mary Jo Hatch, 1993). But there has not been consensus on a single approach to organizational culture (Mary Jo Hatch, 1993). Apart from Schein's (1985) unitary approach of culture, though there have been many approaches, discussing culture either as sub cultures to maintain social structure or discussing it as symbolic behaviors in different ways (Mary Jo Hatch, 1993). In the 1990's, different scholars started taking culture also as a phenomena in different types (Campbell \& Freeman, Quinn).

Analyzing in detail, it becomes clearer that previous researches define organizational culture mainly either as a dimension approaches or type approaches (Quinn 1988; Campbell \& Freeman 1991; Sheridan 1992; Denison and Mishra 1995; Tsui et al 2011). Though the continuous improvement and development in the organizational culture indicates the importance of the field, yet there is not a single approach to measure organizational culture where all the researchers can make consensus (Ogbonna and Harris, 2000).

\section{Organizational culture as dimension approach}

Considering the dimension approaches of organizational culture; Organization culture profile was developed with fifty four statements by O Reilly et al (1954) after a detailed literature review. O Reilly explored seven dimensions of the organizational culture. Denison \& Mishra (1995) presented three aspects of organizational culture dimensions while Hofstede (1991) declared six dimensions (Tsui et al. 2011).Cheng (1990), Peters and Waterman's (1982) and Liu (2003) also presented their researches representing culture values. These all researches had dimensions defined as innovation, mutual respect, Team orientation, stability, harmony, adaptability, employee participation, uprightness, honesty, social responsibility and performance orientation (Tsui et al, 2011). A great extent of research focused on the internal integration of the organization and its external adjustment (Schein 1992, Xin et al, 2002).

\section{Organizational culture as type approach}

Exploring and presenting types of the organizational culture, with collaborating different set of dimensions and values, is another very significant approach in the literature of the management research (Tsui et al, 2011). The type approach clusters different values and dimensions in a culture type, reflecting a specific outcome of the organization. It signifies that organizational outcome is more dependent on organizational culture type consisting of different attributes, rather than only on a specific dimension (Miller et al, 1984; Ketchen et al, 1997). Four culture types, Consistency, Adaptability, Mission and Involvement were proposed by Denison \& Mishra (1995). Daft (2005) proposes it as Adaptability, Clan, Achievement and Bureaucratic while Wallach (1983) presented as Bureaucratic, Innovative and Supportive as cited by (Lee \&Kamarul, 2009). Cameron \& Freeman (1991) presented four very well known types of Market, Hierarchy, Clan and Adhocracy cultures. Cameron \& Freeman (1991) approach uses Competing Values Framework, developed by Campbell (1974), frequently use in research, to distribute the four items in 100 points.Deshpande et al (1993) also developed the instrument which was a modification of Cameron \& Freeman (1991) using the Likert scale of seven, rather than 100 points, because of its easier use. Deshpande et al (1993), model of Market, Adhocracy, Clan and Hierarchy was also used by many researchers' e.g.Ogbonna and Harris (2000) with thelabels ofCompetitive, Innovative, Community and Bureaucratic cultures.

These culture types are representative of either the internal integration or external positioning and either flexibility and either individuality or stability and control (Cameron \& Quinn, 1999; Esra et al, 2011). Clan culture focuses on internal preservation and elasticity, care for own employees and for clients. It is family like well knitted, and goal oriented. Leader is likea mentor. Cooperation, cohesiveness, faithfulness are appreciated. Hierarchy culture is also concentrated on internal preservation with a need for solidity and control. This is culture with formal standards, procedures and rules. This is a bureaucratic environment. Success is measured with the individual's task achievement within the procedures and control of the system. External positioning with a high degree of elasticity and freedom is focused by innovative culture. Here, leaders are like entrepreneurs. This is like a temporary organization where teams are created and dismissed with the new assignments. Innovation and creativity is the key here. Market or competitive culture concentrates on external protection with requirement ofsteadiness and power. Earning profit from the market competition is the key here. Success is measured on the achievements from the market for the organization (Cameron and Quinn, 1999; Mehdi et al, 2010, Esra et al, 2011). The four major attributes are; values, leadership, bonding and strategic emphasis (Lund, 2003).

\section{Outcomes of organizational culture}

Culture has an important part in the organization outcomes as proposed by Marcoulides\& Heck (1993). Employee behavior and attitudes are influenced by organizational culture (Marcoulides, Heck 1993). Zhang \&Zheng (2009) describes the importance of Job performance and Job satisfaction in the human resource management literature. Employee satisfaction may be enhanced and positive work environment with team work can be created with constructive organizational culture which leads to personal satisfaction and organizational goals (Jae San and Tae Hyun 2009). As described by Habib et al (2011), organization citizenship behavior is one of the desired outcomes of the organizational culture. The aim of this research thesis is to find the empirical evidence of the links between Organizational culture different types, employee performance, job satisfaction and turnover in the telecom sector of Pakistan. We will achieve this with the help of this cross sectional study. 


\section{Job satisfaction}

Mind, body and surrounding's satisfaction leads to job satisfaction, while the degree of the satisfaction can be found by asking employees (Hoppock 1935). Bray field \&Rothe (1951)defined Job satisfaction as emotion or sentimental state of employees towards Job. Job satisfaction has been widely studied in last four decades as mentioned by Lund (2003), referencing to (Currivan, 1999).Locke (1969) defined job satisfaction as "pleasurable or positive emotional state resulting from an appraisal of one's job. Locke (1969) also presented it as what one expects from his job at offering and what one wants from it. "An emotional affective response to a job or specific aspect of a job" was presented by (Spector1985). Three different previous circumstances about job role ambiguity, role overload \& conflict were presented by Agho et al. (1993). The more informative employee about his job will be more satisfied and more productive about his job comparative to the employee with less complete information of his job (James A Breaugh 1981).

There are normally three types of job satisfaction (Chang \& Lee, 2007);

1. Integral

2. Differential

3. Reference Structure

Employee's job attitude focusing on mental change for his job satisfaction is integral as defined by Locke (1976). Differential satisfaction is the difference of deserved reward and expected reward of employee, the bigger gap represents less satisfaction (Hodson, 1991). Homans (1961) suggests that subjective characteristics of the organizations also impact satisfaction like the objective characteristics of the organization.

\section{Turnover}

Turnover is very complex but significant area of research having lot of studies discussing this problem (Iverson, 1999). Maertz and Campion (1998)signified it mentioning thousands of studies on the complexity of the problem. Turnover also has financial impacts on the organization as mentioned by (Kangan, 1948) and quoted by Iverson (1999).

Previous researchers Lee \&Mowday (1987) and Lee (2000) also have discussed that turnover intention is the most critical indicator of turnover. Employees' perception of the organizational culture influences the turnover (Sheridan 1992).Job satisfaction has also been a critical predictor of turnover (Jae San and Tae Hyun 2009).

Employee's turnover is categorically described in three types: 1 . Unpreventable turnover (due to family issues, illness), 2. Undesirable turnover (due to incompetency of employee); 3.Desirable turnover (bad governance, poor support, role conflict). Undesirable turnover have to be addressed by the organization because it can harm organizational effectiveness (Miseung Shim 2010). Price (1977) describes turnover as two types: Voluntarily turnover and involuntarily turnover. The voluntarily turnover is with the willingness of the employee and he moves across organization with his initiation. While the other type i.e. is involuntarily turnover is not initiated by the employees.

Organizational shocks play an important role in employee's initiation to leave organization, Lee and Mitchel (1994) explains that these organizational shocks may be expected or unexpected, having a major role in employee's resignation or turnover. Unavoidable turnover is seen as harmful for the organization (Watrous, Huffman and Pritchard, 2006).

\section{Employee performance}

Rotundo and Sackett (2002) classically define performance as "Behaviors under the control of an individual that advance the goals of an organization”. Borman \& Motowidlo (1993) proposed that work centered behavior (essential) and background centered behavior (ethical and extra-role) jointly define job performance.

In-role and extra-role are two main aspects of employee performance (Soumendu and Arup 2007). Employees perform extra-role performance outside their defined job boundaries, whereas in-role duties are within the job description (Williams and Anderson, 1991).
Literature has mainly focused on in-role performance (Murphy and Cleveland, 1995). Strength of organizational culture is a critical management attribute which influences the performance (Macintosh and Doherty 2010).

Core task behaviors, representing formal job responsibilities and organization citizenship behaviors, representing informal extra job role responsibilities, are the two modified measures to identify and measure performance (Stefanie, Courtney and Miguel, 2009).

Orgen (1983) used the term of Organizational citizenship behavior, initially, though there have been many terminologies used in the past for example, "innovative and spontaneous behavior" by (Katz \&Kehn, 1970s), and "Willingness to cooperate" by (Chester Barnard, 1938), etc having a distinction with role performance as quoted by (Habib at el, 2011).

Managers and staff sometimes take responsibility and performance differently, but in the long run OCB impacts significantly the employee's extra role behaviors with their main tasks (Castro, Armario and Ruiz, 2004).

Organizational citizenship behavior as mentioned by Batman and Organ (1983), have expressed as;

1. Beyond the structural and formal matters of organization, the supportive and corporative behaviors for punctuality and completing tasks.

2. Avoiding conflicts and behaviors harmful to other employees and organizations.

Borman and Motwidlo (1993) focus on mainly four points mentioning the importance of OCB:

These points stress the importance between the link of employee's performance of OCB and the organizational effectiveness,

1. Global completion of human resources

2. Team based organizations

3. Organizational changes and organizational performance

4. Customer satisfaction and customer service

\section{Theoretical framework}

Behaviors of an organization and its members are prejudiced by the organizational culture as a broad concept of ideology, tradition and technology (Lee, 1999). (Marcoulides and Heck, 1993) also presented that cultural factors have an impact on the organizational outcomes. Employee satisfaction and turnover is impacted by the organizational culture as is described in previous studies (Jae San and Tae Hyun 2009). Empirical studies describe that strength of organizational culture is a critical management attribute that influences the performance (Macintosh and Doherty 2010). Across industries, personal turnover is strongly predicted by the employee's behavioral intention to leave (Gregory et al., 2007). Moreover, employees are affected at all levels by the different types and attributes of the organizational culture which affects the organizational behavior and functioning (Habib et al, 2011). As Landry and Vandenberghe (2011) suggest that resources and conditions influence the performance of the employees. As this is evident from the past research that Organizational culture impactssignificantly on employee's performance, satisfaction and turnover, we try to make the conceptual model of our study.

In this study a conceptual model that incorporates organizational culture, employee performance, satisfaction and turnover is based on the frameworks applied in the different industries during previous studies, regarding the causes and effects of Organizational culture on all these three important employee variables (performance, satisfaction and turnover).

Research proposes (Deshpande et al, 1993; Lund, 2003) that each organization is composite of mixture of cultures and each culture type has its own attributes (flexibility, stability, formal structures, and informal relations) and importance for organization. It is unfair to declare which culture type is better and what not, but the dominant culture of an organization can be found (Lund 2003, Esra et al, 2011). Therefore our research model explores the impacts of all four culture types separately, on the employee's outcomes of performance, satisfaction and turnover in the telecommunication sector of Pakistan. 
This study labels the four cultures as Community, Innovative, Competitive and Bureaucratic for being more understandable and practical as used by Ogbonna\& Harris (2000).

Following these findings, the study hypothesizes that Organizational culture types impacts directly on employee performance, satisfaction, and turnover. Lund (2003), Ogbonna\& Harris (2000) prefers Campbell \& Freeman (1991), Quinn (1988) and Desphande (1993) approaches, on vertical axis as organic process (Community and Innovative) to mechanical process (Competitive and Bureaucratic), while on horizontal axis as external positioning (Innovative and Competitive) to internal integration (Community and Bureaucratic). Slater \&Narver (1994) propose that organizations on external focus result in better performance. Deshpande et al (1993) ranks performance as (competitive, innovative, community and bureaucratic), cited by Lund (2003), but also cites (Lock, 1970) as the phenomena of happy worker as a productive worker should not be overlooked. Ogbonna\& Harris (2000) also supports that organizational culture types of competitive and innovative will have more positive impact on performance, then community and bureaucratic organizational culture. Greenley (1995) also presents that external focused cultures increase performance.

Odom et al (1990) concluded that employees will have less job satisfaction in bureaucratic culture. Nystrom (1993) presented that weak cultures (less bonding) will have less job satisfaction than strong cultures (more bonding). Lund (2003) presented that organic cultures (community and innovative) will have more job satisfaction for their employees than organizations with mechanical process culture approach (competitive and bureaucratic). Egan et al (2004) also studied the organizational culture, satisfaction and turnover, hypothesizing that Organizational culture will impact both satisfaction and the turnover. Research also proposes that with more job satisfaction employee will be emotionally better attached with the organization.

Research shows that innovative (Adhocracy) and community (Clan) subcultures had positive association with commitment and low turnover, while a bureaucratic subculture had a slight negative association with commitment, and high turnover (Lok\&Crawfold 1999; Mehdi et al, 2010). Clan (Community) culture has the highest level of employee effectiveness (Cameron \& Freeman, 1991). Employees in highly integrative (community \& innovative) culture have more intent to stay in the organization and have more positive attributes towards organization (Tsui et al, 2011). Deal \& Kennedy (1982) supports a highly integrative culture, rather than bureaucratic culture. Carston\& Spector (1987) present that more satisfied employees are less likely to leave. Figure 1 shows the research framework of the study based on above cited studies.

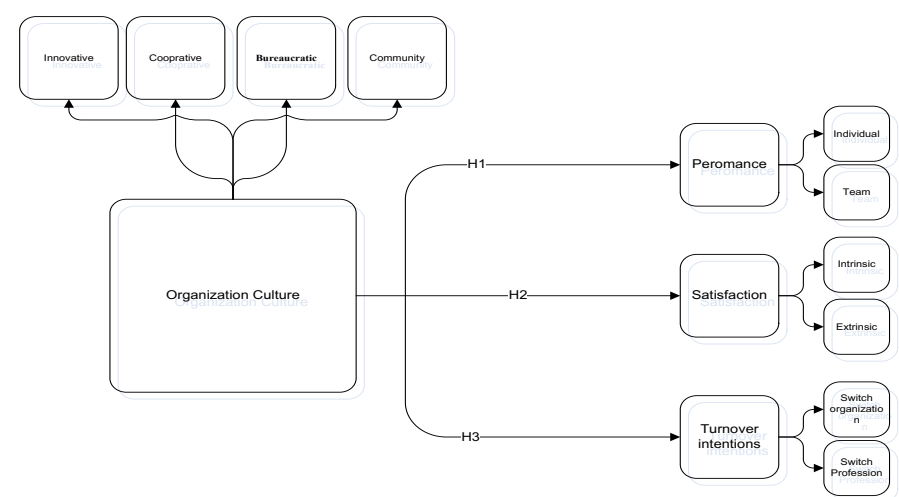

Fig. 1. Research Model

Organizational Culture is the independent variable of this research study. The organizational culture is an old concept in the field of research and has many different approaches for its measurement. Both Dimensions and Types approaches have been discussed in the previous chapter. This study focuses on the Organizational culture types approach. The commonly used tool for the measurement of this phenomenon Organizational culture is Campbell and Freeman (1991).
Deshpande et al (1993) modified it and this scale is used in this study as well. This scale assesses the organizational culture as four types, Competitive, Bureaucratic, Community and Innovative, with the help of sixteen items. Many of the studies have been conducted using this for example (Ogbonna and Harris, 2000) observed the cumulative variance of $60 \%$. The statements of the scale are following;

This company emphasizes,

1. Growth and acquiring new resources. Readiness to meet new challenge is important.

2. Permanence and stability. Efficient, smooth operations are important.

3. Human resources. High cohesion and morale in the firm are important.

4. Competitive actions and achievement. Measureable goals are important.

The second statement was;

To what extent does your company place a high priority on the following?

5. This company is dynamic and entrepreneurial. People are willing to take risks.

6. This company is production oriented. The major concern is with getting the job done. People are not very personally involved.

7. This company is very formalized and structured. Established procedures generally govern what people do.

8. Company is personal. It is like an extended family.

The third statement was;

In this company the best managers are considered to be;

9. Entrepreneurs, innovators or risk takers.

10..Producers, technicians or hard-drivers.

11. Co- coordinators, organizers or administrators.

12. Mentors, sages or father/mother figures.

The $(1=$ Not at all, and $7=$ Very great extent $)$ were the seven options to reply for each item for respondents.

The fourth statement was;

The glue which holds the company together is:

13. Commitment to innovation and development. There is an emphasis on being first.

14. An emphasis on tasks and goal accomplishment. A production orientation is shared.

15. Formal rules and policies. Maintain a smooth-running company is important here.

16. Commitment to this firm runs high. Loyalty and tradition are important here.

The $(1=$ Very False, and $7=$ Very True $)$ were the seven options to reply for each item for respondents.

The study has three dependent variables which are described below;

\section{Employee performance}

Employees Performance is the first dependent variable of this research study. Likertscale of 5 points developed by William and Anderson (1991) was used to measure employee performance having ranges of " $1=$ strongly disagree" to " $5=$ strongly agree". The nine statements of employee performance measure were "Attendence above the norm", "Help who have heavy work load", "Assisting supervisor", "Adequately completes assigned duties", "Performs tasks that are expected of him/her", "Meets formal performance requirements of the job", "Advance notice when unable to come to work", "Protect organizational property", "Pass information to coworkers".

\section{Employee satisfaction}

Agho, A.O, Price, J.L., Miller, C.W., (1992) instrument of 6 items on Likert scale was used to measure the second dependent variable of the study i.e. employee job satisfaction, Those 6 statements of satisfaction measure were, "bored with my job (R)", reverse statement, "fairly satisfied with my job", "satisfied with my job for time being", ", "Enthusiastic about my job", "Like my job more than average worker does", "Find real enjoyment in my work". 


\section{Employee turnover}

The third dependent variable of the study is Turnover, as turnover intention is the sole most critical driver of the turnover; turnover intention is taken as turnover. 3 item Likert scale was used developed by MichiganOrganizational Assessment Questionnaire, developed by Seashore et al (1982) with three statements. These statements were "Look for a new job next year", "Often thinks about Quitting", "Finding about another job with same pay and benefits".

It is consistently explored in research that because of the versatility of the organizational culture, its different aspects have different influence on employee's attributes (Sheridan, 1992; Lund 2003; Egan at el, 2004; Macintosh and Doherty 2010). These hypothetical relationships are based on empirical findings, this study explores that different organizational culture types have different direct impacts on employees performance, satisfaction and turnover in Pakistan telecommunication sector.

Based on the research model and above findings, the hypotheses of the study are;

H1: The impact of organizational culture on employee performance ranges from best to worst along field of external focus (Competitive and innovative culture) to internal focus (Community and Bureaucratic culture).

$\mathrm{H} 2$ : The impact of organizational culture on employee satisfaction ranges from most to least along field of organic processes (Community and innovative culture) to Mechanistic processes (Competitive and Bureaucratic culture).

H3: The impact of organizational culture on employee turnover ranges from minimum to maximum along field of organic processes (Community and innovative culture) to Mechanistic processes (Competitive and Bureaucratic culture).

\section{Research design}

\section{Population}

Employees of the telecom sector organizations of Pakistan were the population of this research. Telecommunication is one of the most rapidly developing sectors of Pakistan. The population for the study was taken from the twin cities of Rawalpindi and Islamabad from organizations like PTCL, Ufone, Mobilink, China Mobile, Nokia Siemens Networks, Huawei and ZTE, approximately 12000 employees from the respective organizations. The respondents were from staff, supervisor, lower, middle and top management of the organization.

\section{Sample and data collection}

Data has been collected about the organizational culture in the number of past studies using a questionnaire; e.g. (Boxx et al, 1999, Lund, 2009). I also used the self-administrated questionnaire with the distribution to the different organizations employees. The privacy and confidentiality of the respondent were assured to all employees, ensuring the purpose of research for the effort. All the questions were asked in English language because of its understandability and avoid translation. The researcher was also present to help, if any issue regarding the translation of statements was raised. Initially almost 400 employeeswere contacted and requested for their precious time through the personal contacts with the permission of competent authorities. Only 260 questionnaires were returned back from the respondents out of 400 , with the encouraging response rate of $65 \%$. The questionnaire had two parts Part one of the questionnaire was about the employees attributes i.e. employee's performance, satisfaction and turnover intention. Second part of the questionnaire was about the measurement of Organizational Culture. Organizational culture questions were quite time consuming because it was often very difficult to manage time for the busy employees of the rapid telecom industry.

\section{Measures / scales}

Likert scale was used to measure the responses regarding all the variables. 7 point scale was used for organizational culture, carrying the anchors ranging from Not at all to Very great extent. 7 point scale,was also used for Turnover, having ranges of Strongly Disagree to Strongly Agree. Performance and Satisfaction were both measured on 5 point scale, having ranges from Strongly Disagree to Agree. $5=$ 'Strongly agree' 4= 'Agree', 3= 'Neither agree nor disagree', 2= 'Disagree', 1="Strongly disagree'. The independent variable of the study was Organization Culture. The dependent variables were Employee Performance, Satisfaction and Turnover. Job satisfaction also was analyzed as the mediating Variable between Organizational Culture and Employee Performance, and between Organizational Culture and Employee Turnover. Below are presented the details of the variables and measuring instruments.

\section{Results}

The demographic variables which were measured are Gender, age, education, experience, and the level in organization. Table 1 shows the demographic statistics of the respondents.

Table 1: Data Collection on the Basis of Gender

\begin{tabular}{lllll}
\hline Total Resp & Male Resp & Female Res & \% Male & \% Female \\
\hline 249 & 174 & 75 & 69.87 & 30.12 \\
\hline
\end{tabular}

There are 249 respondent's data was available for this research. 174 employees were male while 75 were female. It means the male employees make the $69.87 \%$ of the total respondents, while this figure is $30.12 \%$ of the females. Showing female are almost one third of the male but still representing strongly, considering a relatively conservative but evolving society of the country. It shows that females are also an integral and strong part of Pakistan telecom sector. Table 2 shows the respondents income range.

\begin{tabular}{lll}
\multicolumn{2}{l}{ Table 2: Data Collection on the Basis of Income } \\
\hline Salary Level in PKR & Number Of Respondents & \% with Salary \\
\hline $0-25000$ & 87 & 34.93 \\
$25001-50000$ & 109 & 43.77 \\
$50001-100000$ & 46 & 18.47 \\
$100001-200000$ & 5 & 2.008 \\
200001 and above & 2 & 0.803 \\
\hline
\end{tabular}

From the total of 249 employees, 87 had the salary up to 25000,109 had the salary range between 25000 and 50000,46 had the salary between 50000 and 10000,5 have the salary above 100000 and below 200000. 2 of the respondents were above 200000 salary range. It represents that $34.93 \%$ of employees have the salary range up to $25000,43.77 \%$ had up to 50000 . 18.47 have the limit till 100000 . Only $2 \%$ had till 200000 , and $0.803 \%$ above this. Table 3 shows the ages of the respondents.

Table 3: Data Collection on the Basis of Age

\begin{tabular}{lll}
\hline Age Group & Number Of Respondents & $\%$ of Age \\
\hline $20-30$ years & 119 & 47.79 \\
$31-40$ years & 114 & 45.78 \\
$41-50$ years & 13 & 5.22 \\
$51-60$ years & 2 & 0.803 \\
60 and above & 1 & 0.401 \\
\hline
\end{tabular}

The sample size for the study was 250 . Out of this, 119 employees had the age between 20 years to 30 years, 114 employees had the age between 31 years to 40 years. Between 41 to 50 years only 13 employees' participated, and just two employees had the 50 years to 60 years of age, only one employee was above 60 years of age. Table 4 shows the management position of the respondents.

Table 4: Data Collection on the Basis of Position

\begin{tabular}{lll}
\hline Position & Number Of Respondents & \% of Position \\
\hline Staff & 56 & 22.48 \\
Supervisor & 51 & 20.48 \\
Lower Management & 94 & 37.75 \\
Middle Management & 45 & 18.07 \\
Top Management & 3 & 1.20 \\
\hline
\end{tabular}


56 employees were of staff level among the total of 250 sample, 51 employees were supervisor, out of 250 employees, 94 were from lower management, from middle management, 45 employees participated. Only three employees among respondents were from the top management of the organizations. Table 5 shows the industry type where the respondents work.

Table 5: Data collection on the Basis of Industry Type

\begin{tabular}{lll}
\multicolumn{2}{l}{ Table 5: Data collection on the Basis of Industry } & Type \\
\hline Industry Type & Number Of Respondents & \% of Industry Type \\
\hline Sub contractor & 91 & 36.54 \\
Contractor & 62 & 24.89 \\
Service & 97 & 38.95 \\
Providers & & \\
\hline
\end{tabular}

Out of the 250 respondents, 91 were from the sub contractors, 62 respondents were from the contractors and 97 of the respondents were from the service providers.

The measurement scale used was the interval scale having five intervals for performance and satisfaction and seven intervals for turnover and organizational culture type's data collection. Like, strongly disagree, disagree, neutral, agree and strongly agree. Table 6 shows the reliability of the questionnaire.

Table 6: Reliability of the Questionnaires

\begin{tabular}{ll}
\hline Variables & Cronbach's Alpha \\
\hline Performance & 0.86 \\
Satisfaction & 0.81 \\
Turnover & 0.65 \\
Innovative Culture & 0.61 \\
Bureaucratic Culture & 0.6 \\
Community Culture & 0.6 \\
Competitive Culture & 0.65 \\
\hline
\end{tabular}

Reliability was tested for Performance, Satisfaction, Turnover, Innovative Culture, Bureaucratic Culture, Community Culture and Competitive Culture, and was accepted. Performance and Satisfaction had more reliability than others. The reliability of all other variables was also good. The acceptability of Bureaucratic and Community Cultures were less than others but acceptable. Bureaucratic culture was at 0.5 , but when we omitted the question number 25 , it became reliable. Table 7 shows the descriptive statistics of the variables.

Table 7: Descriptive Statistics

\begin{tabular}{lll}
\hline Variables & Mean & Std. Deviation \\
\hline Performance & 4.0032 & .59879 \\
Innovative & 3.2544 & .56041 \\
Competitive & 3.1812 & .54802 \\
Community & 3.3432 & .59649 \\
Bureaucratic & 3.2936 & .44976 \\
\hline
\end{tabular}

Data ranges for every variable was considered which helped to explore variables. For performance, the data range was between ( 3 to 5) showing that most of the employees responses were agreed. All four culture types, innovative, bureaucratic, community and competitive, range was between 3 and 4representing employees were slightly agreed. That is why; in general we can declare that most of the employees were agreed, on the questions asked for every independent variable for dependent variable of Performance. Table 8 shows the correlation matrix of the study.

Table 8: Correlation Matrix

\begin{tabular}{lccccccc}
\hline & Perf & Sat & TO & Inn & Bur & Comm & Comp \\
\hline Perf & 1.00 & & & & & & \\
Sat & 0.19 & 1.00 & & & & & \\
TO & 0.09 & 0.11 & 1.00 & & & & \\
Inn & 0.19 & 0.62 & 0.09 & 1.00 & & & \\
Bur & 0.21 & 0.77 & 0.08 & 0.62 & 1.00 & & \\
Comm & 0.11 & 0.80 & 0.14 & 0.67 & 0.60 & 1.00 & \\
Comp & 0.20 & 0.56 & 0.33 & 0.48 & 0.58 & 0.44 & 1.00 \\
\hline Per=Performance, & \multicolumn{7}{c}{ Sat=Satisfaction, $\quad$ TO=Turnover, Inn=Innovative, } \\
Bur=Bureaucratic, Comm=Community, Comp=Competitive &
\end{tabular}

Correlation measures the strength of the relationshipof two variable, correlation values ranges from 0 to 1 . Correlation above 7 is strong relation. It helps us to find the type, strength and direction of relation. Pearson correlation was used to explore the data describing that performance and all four culture types have positive relationship. Bureaucratic culture has the post positive relation with performance among all four culture types. Community and innovative culture has almost same relationships, while competitive culture has the weakest positive relationship with performance. Table 9 shows the regression results.

Table 9: Multiple Regression Analysis

\begin{tabular}{llll}
\hline Model & $\begin{array}{l}\text { Standardized Coefficients } \\
\text { Beta }\end{array}$ & $\mathbf{T}$ & Sig. \\
\hline Innovative & .139 & 2.546 & 0.045 \\
Competitive & -.101 & -3.156 & 0.001 \\
Community & .105 & 2.356 & 0.051 \\
Bureaucratic & .119 & 1.311 & 0.191 \\
\hline
\end{tabular}

Adjusted R-Square: 0.651; F-statistics: 5.858; Prob. Value: 0.000 The results show that all variables have a correct sign as per expectations, however, Bureaucratic variable insignificantly explain the dependent variable.

Constant is the intercept of the regression line. Significance 0 is the validity of the model. Standardized coefficient Beta reflects the slope, means if we convert all the variables in the $\mathrm{Z}$ values (means of zero and standard deviation of 1), this means intercept becomes zero. The value of constant at inferential $t$ test is 10.424 . It is significant at 0.00 which shows the validity of the model. The $t$ value informs us the dependent and independent variables relationship. It tells the impact of independent variables on the performance that is the dependent variable. In this study, all the organizational culture types have insignificant relationships with the performance variable, so we can predict the impacts of each culture type on performance.

\section{Hypothesis testing of organizational culture types and satisfaction}

H2: The impact of organizational culture on employee satisfaction ranges from most to least along field of organic processes (Innovative and Community culture) to Mechanistic processes (Competitive and Bureaucratic culture).

Table13: Descriptive Statistics

\begin{tabular}{lll}
\hline Variables & Mean & Std. Deviation \\
\hline Satisfaction & 3.2560 & .47684 \\
Innovative & 3.2544 & .56041 \\
Competitive & 3.1812 & .54802 \\
Community & 3.3432 & .59649 \\
Bureaucratic & 3.2936 & .44976 \\
\hline
\end{tabular}

The range of the data of every variable was calculated in this research study for performance variable and dependent variables, which supported to explore that where on the interval scale each variable data falls. All five variables Satisfaction, innovative culture, bureaucratic culture, community culture and competitive culture had respondent values lying between; ( 3 and 4 ) mentioningthat the respondents were slightly agreed. That is why; overall most of the employees were partially agreed and agreed as the responses for questions asked for every variable.

Pearson correlation was applied for analysis. A strongly positive relationship between satisfaction and competitive culture is shown in the table; bureaucratic culture also has a very strong relationship with satisfaction. The relationship of innovative culture is also strong with satisfaction. Community culture also has a positive strong relationship with satisfaction, but in comparison with other culture variables, community culture has a less strong relationship. 


\begin{tabular}{|c|c|c|c|c|c|c|}
\hline & & Sat & Inn & Comp & Comm & Bur \\
\hline \multirow[t]{5}{*}{ Pearson Correlation } & Sat & 1.000 & .621 & .797 & .557 & .774 \\
\hline & Inn & .621 & 1.000 & .661 & .475 & .628 \\
\hline & Com & .797 & .661 & 1.000 & .432 & .607 \\
\hline & Comp & .557 & .475 & .432 & 1.000 & .579 \\
\hline & Bur & .774 & .628 & .607 & .579 & 1.000 \\
\hline \multirow[t]{5}{*}{ Sig. (1-tailed) } & Sat & . & .000 & .000 & .000 & .000 \\
\hline & Inn & .000 & . & .000 & .000 & .000 \\
\hline & Com & .000 & .000 & . & .000 & .000 \\
\hline & Com & .000 & .000 & .000 & . & .000 \\
\hline & Bur & .000 & .000 & .000 & .000 & . \\
\hline
\end{tabular}

Bur=Bureaucratic

Table 15: Model Summary

\begin{tabular}{lll}
\hline $\mathbf{R}$ & $\mathbf{R}$ Square & Adjusted R Square \\
\hline $.881^{\mathrm{a}}$ & .776 & .772 \\
\hline
\end{tabular}

As in case of performance, hypothesis is analyzed using regression. In the above table, we can see the results of regression of the four independent variables (innovative, community, competitive and bureaucratic. $\mathrm{R}$ is the correlation of four independent variables with satisfaction. Variance is R-sqr. This model summary shows that there is $88.1 \%$ relationship among satisfaction and innovative, community, competitive and bureaucratic cultures.

Table 16: Variance Analysis (ANOVA)

\begin{tabular}{lllllll}
\hline Model & \multicolumn{2}{l}{$\begin{array}{l}\text { Sum of } \\
\text { Squares }\end{array}$} & df & Mean Square & F & Sig. \\
\hline 1 & Regression & 43.929 & 4 & 10.982 & 212.071 & $.000^{\text {a }}$ \\
Residual & 12.687 & 245 & .052 & & \\
\multicolumn{1}{l}{ Total } & 56.616 & 249 & & & \\
\hline
\end{tabular}

a. Predictors: (Constant), Bureaucratic, Community, Competitive, Innovative

b. Dependent Variable: Satisfaction

For this research the value of $\mathrm{F}$ came out to be 212.071 i.e. $212 \%$, which indicates the best fitness of this model for satisfaction. This value was significant at 0.00 significantlevels and it was signified by value of $F$.

Table 17: Coefficients

\begin{tabular}{llll}
\hline Variables & $\begin{array}{l}\text { Standardized Coefficients } \\
\text { Beta }\end{array}$ & $\mathbf{T}$ & Sig. \\
\hline Innovative & -.038 & -.863 & .389 \\
Competitive & .522 & 12.214 & .000 \\
Community & .107 & 2.832 & .005 \\
Bureaucratic & .418 & 9.414 & .000 \\
\hline
\end{tabular}

Relationship of dependent and independent variables is found by value of $t$. In this research study as the value of $t$ is greater for competitive culture at 12.214 with significance of 0.00 so, its impact will be the most on satisfaction. Then the value of $t$ for Bureaucratic is 9.414 with significance of 0.00 which is also very significant and having a very strong impact on satisfaction in Pakistan telecom sector. The value of $\mathrm{t}$ for Community culture is 2.83 with significance of 0.005 , showing its impact on satisfaction. The value of $t$ is negative with Innovative culture means it is inversely related to job satisfaction, but it also shows 0.389 significance level, which is not significant. The variables with the greater value of $t$ also represent more value for beta.

\section{Hypothesis Testing of Organizational Culture Types and Turnover}

H3: The impact of organizational culture on employee turnover ranges from minimum to maximum along field of organic processes
(Community and innovative culture) to Mechanistic processes

(Competitive and Bureaucratic culture).

Table 18: Descriptive Statistics

\begin{tabular}{lll}
\hline Variables & Mean & Standard Deviation \\
\hline Turnover & 3.2992 & .60579 \\
Innovative & 3.2544 & .56041 \\
Competitive & 3.1812 & .54802 \\
Community & 3.3432 & .59649 \\
Bureaucratic & 3.2936 & .44976 \\
\hline
\end{tabular}

As described above for the performance and satisfaction variable, with the help of this descriptive analysis the central tendency and the dispersion can be found out. Turnover has the respondents range between ( 3 and 4 ), indicating that the respondents were slightly agreed upon the question.

\section{Table19: Correlations}

\begin{tabular}{lllllll}
\hline & & TO & Inn & Comp & Comm Bur \\
\hline Pearson Correlation & TO & 1.000 & -.066 & .020 & .139 & -.070 \\
& Inn & -.066 & 1.000 & .661 & .475 & .628 \\
& Comp & .020 & .661 & 1.000 & .432 & .607 \\
& Comm & .139 & .475 & .432 & 1.000 & .579 \\
& Bur & -.070 & .628 & .607 & .579 & 1.000 \\
Sig. (1-tailed) & Inn &. & .151 & .378 & .014 & .134 \\
& Comp & .151 &. & .000 & .000 & .000 \\
& Comm & .378 & .000 &. & .000 & .000 \\
& Bur & .014 & .000 & .000 &. & .000 \\
& Inn & .134 & .000 & .000 & .000 &. \\
\hline TO=Turnover, & Inn=Innovative, & Com=Competitive, & \multicolumn{2}{c}{ Comm=Community, } \\
Bur=Bureaucratic & & & & & & \\
\end{tabular}

As discussed above, for the data analysis we have used Pearson correlation. As this table shows that competitive and community culture has weak positive relationship with the turnover, while innovative and bureaucratic culture has negative relationship with turnover. It shows that bureaucratic and innovative cultures have the least impact on turnover while community and competitive cultures have the most impact.

Table 20: Model Summary

\begin{tabular}{lll}
\hline $\mathbf{R}$ & $\mathbf{R}$ Square & Adjusted R Sqr \\
\hline $.257^{\mathrm{a}}$ & .066 & .051 \\
\hline
\end{tabular}

As above for performance and satisfaction variables, regression is used for analysis. The results of regression of the four independent variables (innovative, community, competitive and bureaucratic)are described in the above table. $\mathrm{R}$ is the correlation of four independent variables with turnover which .257. R-sqr is the variance. Relationship among turnover and innovative, community, competitive and bureaucratic culture types is $25.7 \%$.

Table 21: Variance Analysis (ANOVA)

\begin{tabular}{llllll}
\hline Model & Sum of Squares & Df & Mean Square & F & Sig. \\
\hline 1 Regression & 6.043 & 4 & 1.511 & 4.337 & $.002^{\mathrm{a}}$ \\
Residual & 85.337 & 245 & .348 & & \\
Total & 91.380 & 249 & & & \\
\hline a. Predictors: (Constant), Bureaucratic, Community, Competitive, Innovative \\
b. Dependent Variable: Turnover \\
4.33\% is the F value in this model, and was significant at 0.02 significance level.
\end{tabular}

As demonstrated in case of performance and satisfaction, we analyze the beta, $t$ value and significance here. Value of $t$ for community culture is at 3.620 with significance of 0.00 so, its influence will be the most on turnover. Then the value of $t$ for competitive culture is 1.472 with significance of 0.14 , it means it is insignificant. The value of $\mathrm{t}$ for innovative culture and bureaucratic culture means it is 
inversely related to turnover, but it also shows 0.10 and 0.17 significance level respectively which is not much significant.

\begin{tabular}{llll}
\multicolumn{2}{l}{ Table 22: Coefficients } \\
\hline Model & $\begin{array}{l}\text { Standardized Coefficients } \\
\text { Beta }\end{array}$ & $\mathbf{t}$ & Sig. \\
\hline Innovative & -.146 & -1.631 & .104 \\
Competitive & .128 & 1.472 & .142 \\
Community & .279 & 3.620 & .000 \\
Bureaucratic & -.218 & -2.403 & .017 \\
\hline
\end{tabular}

\section{Results}

Folling is the summary of the results of the current study

Table 23: Summary of Results of the current study

\begin{tabular}{|c|c|}
\hline Hypothesis & Result \\
\hline $\begin{array}{l}\text { H1: The impact of organizational culture on employee } \\
\text { performance ranges from best to worst along field of } \\
\text { external focus (Competitive and innovative culture) to } \\
\text { internal focus (Community and Bureaucratic culture). }\end{array}$ & $\begin{array}{l}\text { Do Not } \\
\text { Reject }\end{array}$ \\
\hline $\begin{array}{l}\text { H2: The impact of organizational culture on employee } \\
\text { satisfaction ranges from most to least along field of } \\
\text { organic processes (Community and innovative culture) } \\
\text { to Mechanistic processes (Competitive and } \\
\text { Bureaucratic culture). }\end{array}$ & $\begin{array}{l}\text { Do Not } \\
\text { Reject }\end{array}$ \\
\hline $\begin{array}{l}\text { H3: The impact of organizational culture on employee } \\
\text { turnover ranges from minimum to maximum along field } \\
\text { of organic processes (Community and innovative } \\
\text { culture) to Mechanistic processes (Competitive and } \\
\text { Bureaucratic culture). }\end{array}$ & $\begin{array}{l}\text { Do Not } \\
\text { Reject }\end{array}$ \\
\hline
\end{tabular}

Analyzing the impacts of organizational culture types with performance, the descriptive statistics shows a tendency between (45) means Agree and strongly agree. But for the four cultural types, the value of innovative, community, competitive and bureaucratic ranges between (3-4) means people are slightly agree with the most of the culture types. The correlation of the culture types with performance represents that bureaucratic, innovative and community cultures have the best positive relations with performance with slight differences, while the relationship of competitive culture with the focus on market and new business is lesser with performance. Our research model is significant as it has the $\mathrm{R}$ value of $25 \%$, and significant level of .004. The value of $F$ is 4.01 , while $R^{2}$ is .06 and adjusted $R^{2}$ is .046 . Coefficients results represent that innovative culture has the beta and $\mathrm{t}$ value, followed by community and bureaucratic cultures. The competitive culture shows the negative beta and $t$ value for performance, but with most insignificant results among all four independent variables. That is why we cannot reject our hypothesis because the innovative culture showed a positive result but competitive culture result was insignificant.

Exploring the results of all four organizational culture types on the dependent variable, satisfaction; the descriptive statistics table shows the tendencies of satisfaction variable, almost same as for culture types. It describes that the mean value of satisfaction is slightly higher that mean value of 3 , i.e. the slightly agree response to satisfaction. It shows some hesitant of the respondents that they might be confuse about their satisfaction. While in the case of performance, they were very confident. Competitive and bureaucratic cultures show the best relation with satisfaction, followed by innovative and community cultures. The model summary demonstrates the value of $\mathrm{R}$ as .88 , while $\mathrm{R}^{2}$ and adjusted $\mathrm{R}^{2} .776$ and .772 respectively. The model is very significant, with the significance value of 0.000 and factor value $\mathrm{F}$ as 212. Here competitive and bureaucratic culture types demonstrate the best value of beta and $t$, followed by community culture with very good significance. The innovative culture shows the negative relationship with the satisfaction but its value is insignificant at $38 \%$.

In the third model of the organizational culture types with turnover, descriptive statistics indicates a central tendency of respondents as (3-
4), means slightly agreeing to the turnover, but hesitant to respond. Innovative and bureaucratic cultures have the best relationship with turnover, while the innovative and bureaucratic culture representing negative relationships. Its model summary shows the value of $\mathrm{R}$ as .257 , value of $\mathrm{R}^{2}$ as .066 and adjusted $\mathrm{R}^{2}$ as .051 . The model is significant with the significance level of .002 but with $F$ value of 4.33 . The value of beta and $t$ is the most with community and competitive culture but the relation is insignificant between competitive culture and turnover. There is a significant negative relationship of innovative and bureaucratic culture types with the turnover, predicting a low turnover in these cultures.

\section{Recommendations}

The study has opened a door open for the scholars, management and the government to further deeply analyze the organizational culture in Pakistan and explore their impacts on the employee's outcomes, as stated by (Habib et al, 2011) that managers and theorists always take interest in organizational culture and its outcomes. Government has to make long term and sustainable policies for employee's psychological welfare and mental peace. They should access why the results can be improved up to the international human behaviors standards. While management has to pay attention on the organizational cultures to be more employee's friendly, being remained formal with entrepreneurial spirit and market focused, as Jex (2003) proposed, in order to survive in the competitive environment, organizations has to change the culture. (Habib et al, 2011) also state that management has to change and strengthen the culture to have a competitive advantage. Employees are performing well enough in the bureaucratic and competitive culture too but on the right opportunities in the feasible environment may lead them to change their loyalties. The unsatisfied employees may not perform consistently well over a longer period of time. They may change their loyalty when the circumstances get better and more job opportunities arise. Leaders and managers can overcome the difficulties of organizational culture and circumstances as mentioned by Robbins (2003). Leaders can establish the core values of the company by developing vision (Chang \& Lee, 2007). Tung and Verbeke (2010) mention that international experience can also help to improve cultures; the management should take more vibrant approach to satisfy their employees and keep their loyalty, when their performance is very beneficial for the organization and the industry.As both behavioral and structural factors impact the employees' performance (Habib et al, 2011). Moreover, during merger or acquisitions, organizations should focus not only the economic synergy but also the compatibility between the organizational cultures of the both organizations in process; it paves a long time impact on the future outcomes of the employees as discussed by Lund (2003). Downsizing and layoffs also have impacted the employee relations with the organizations, and now employees change their employers many times in career, that is why, there must be more integration the employee's relationship with the organization for the sustainability and desired outcomes, as also suggested by Lund (2003).

\section{References}

Abbasi, S.M., \&Hollman, K.W. (2000), Turnover: The Real Bottom line, Public Personal Management, 29, 333-342.

Alvesson, M. (2002). Understanding Organizational culture. Thousand Oaks, CA: Sage.

Annelies E.M. Van Vianen, (2000), "Person-Organization Fit: The Match Between New Comers' and Recuriters' Preferences for Organizational Culture", Personnel Psychology, Vol. 53, pp 113-149.

Bashir, U. and Ramay, M.I, (2010), "Impact of stress on employee job performance, A study on banking sector of Pakistan", International Journal of Marketing Studies, Vol.2 No.1 pp. 122-126.

Biswas, Soumendu (2010), "Relationship between psychological climate and turnover intentions and its impact on organizational effectiveness: A study in Indian Organizations", IIMB Management Review, Vol. 22, pp.102110.

Boxx, R.W., Odom, R.Y. and Dunn, M.G. (1991), “Organizational values and value congruency and their impact on satisfaction, commitment and 
cohesion: an empirical examination within the public sector", Public Personnel Management, Vol.20, pp.195-205.

Budhwar, P., Varma, A., Singh, V. and Dhar, R, (2006), "HRM sytems of Indian call centers in India:an exploratory study", International Journal of Human

Cameron, K.S. \& Freeman, S.J. (1991), "Cultural congruence, strength and Type: relationships to effectiveness", Research in Organizational Change and Development, Vol.5, pp-23-58.

Cameron, K.S., \& Quinn, R.E., (1999), "Diagnosing an changing organizational culture based on computing values framework", MA Addison-Wesley.

Campbell, J.P; and Freeman, S.J (1991), "Cultural congruence, Strength and Type: Relationships to effectiveness", In Woodman, R.W. and Passmore, W.A. (eds) Research in Organizational Change and Development, Vol. 5. Greenwich, CT: JAI Press.

Carsten, J.M. and Spector, P.E., (1987), "Unemployment, Job Satisfaction, and employment turnover: a meta-analytic test of Muchinsky model", Journal of Applied Psychology, Vol. 72, pp. 374-81.

Cartwright, S., and C.L., Cooper (1990), "The impact of mergers and acquisitions on people at work: existing research and issues", British Journal of Management, Vol.1, pp. 65-76.

Castro, Armario and Ruiz (2004), "The influence of organizational citizenship behavior, customer loyalty", International Journal of Service Industry Management, Vol. 15 No.1, pp 27-53.

Cemalettinipek (2010), "Predicting Organizational Commitment from Organizational Culture in Turkish Primary Schools", Asia Pacific Educ.Rev.Vol.11, pp.371-385.

Charles A. O Reilly III, Jennifer Chatman, David F. Caldwell (1991), "People and Organizational Culture: A Profile Comparison Approach to Assessing Person-Organizational Fit", The Academy of Management Journal Vol.34 No.3, pp.487-516.

Daniel R. Denison and Aneil K. Mishra (1995), "Toward a Theory of Organizational Culture and Effectiveness", Organization Science, Vol 6 , No. 2, pp. 204-223.

Dennison, D (1984), "Bringing corporate culture to the bottom line", Organizational Dynamics, Vol.13 No.2, pp. 5-22.

Dephande and Frederick E. Webster, Jr. (1989), "Organizational Culture and Marketing: Defining the Rese--arch Agenda”, Journal of Marketing, 53 (January). Pp 3-15.

Deshpande, R., Farley, J.U. and Webster, F.E. (1993), "Corporate Culture, Customer Orientation and Innovativeness in Japanese Firms: A Quadrad Analysis", Journal of Marketing, Vol 57 (Jan): pp. 23-07.

Egan, T.M., Yang, B., \&Barlett, K. (2004), "The effects of organizational learning culture and job satisfaction on motivation to transfer learning and turnover intention". Human Resource Development Quarterly, Vol. 15, pp. 279-301

Eric. W, Macintosh and Alison Doherty (2010), "The influence of organizational culture on job satisfaction and intention to leave", Sport Management Review, Vol. 13, pp.106-17.

Esra, A., Isik, C., Mithat, K., (2011), "The effects of organizational culture on organizational efficiency: The moderating role of organizational environment and CEO values", Procedia Social and Behavioral Sciences, Vol. 24, pp. 1560-1573

Gentry, W.E, and Sparks, T.A. (2011), "A convergence/divergence perspective of leadership competencies managers believe are most important for success in organizations: A cross-cultural multilevel analysis of 40 countries", J Bus Psychol, DOI 10.1007/s10869-011-9212-y

George A. Marcoulides and Ronald H.Heck (1993), "Organizational Culture and Performance: Proposing and Testing a Model", Organization Science, Vol 4, No.2, pp. 209-225

Greenley, G.E. (1995a), "Market Orientation and Company Performance: Empirical evidence from UK Companies", British Journal of Management, Vol.6, No.1, pp. 1-14

Gregory. D.M., Way, C.Y., LeFort, S., Barret, B.J. and Parfrey, P.S. (2007) "Predictors of registered nurses' organizational commitment and intent to stay", Health Care management Review, Vol. 32 No. 2, pp. 119-127.

Jex, S.M. (2003), Organizational Psychology, A Scientist Practitioner Approach, New York: John Wiley.

Habib, E., Adel, Z., Ali, K. and Muhammad, B.S. (2011),"A survey relation between organizational culture and organization citizenship behavior", Procedia-Social and Behavioral Sciences, Vol.30, pp 1920-1925.

Hodson, R. (1991), "Workplace behaviors: good soldiers, smooth operations, and saboteurs", Work and Occupations, Vol.18, No.3, pp.271-90.

Homans, G. C. (1961), Social behavior: Its Elementary Forms, Harcourt, Brace and World, New York, NY.

Hoppock, R. (1935), Job Satisfaction, Harper \& Row, New York, NY.

Iverson, R. D. (1999), “An event analysis history of employee turnover: The case of hospital employees in Australia", Human Resource Management Review, Vol.9 No.4, pp.397-418.
J. Zhang., and W. Zheng (2009), "How does satisfaction translate into performance? An examination of commitment and cultural values", Human Resource Development Quarterly, Vol. 20 No.3

Jae San Park and Tae Hyun Kim (2009), "Do types of organizational culture matter in nurse job satisfaction and turnover intention?", Leadership in Health Sciences, Vol.22, No.1, pp. 20-38

James A. Breaugh (1981), "Relationship between Recruiting Sources and Employee Performance, Absenteeism and Work Attitudes", The Academy of Management Journal, Vol.24, No.1, pp. 142-147.

Kangan, M (1948), "The financial impacts of labour turnover, : A case study at Jacques Bros. Pty. Ltd. Personal practice bulletin, 4, 19-30.

Lambert, E., Hogan, N., and Barton, S. (2001), "The impacts of job satisfaction on turnover intent: a test of structural measurement model using a national sample of workers", Social Science Journal, Vol.38 No.2, pp 233-50.

Laundry, G., \&Vandenberghe, C. (2011), "Relational commitments in employee-supervisor dyads and employee job performance, The Leadership Quartely", doi: 10.1016/j.leaqua.2011.05.016.

Lee, H.Y, and Kamarul Z.B.A. (2009), "The moderating effects of organizational culture on the relationships between leadership behavior and organizational commitment and between organizational commitment and job satisfaction and performance" , Leadership and Organizational Development Journal Vol. 30 No.1, pp.53-86 .

Lee, H.J. (1999), Organizational Behaviour, Sekyung-Sa, Seoul.

Lee, H.Y., and Kamraul, Z.B.A (2009), "The moderating effects of organizational culture on the relationships between leadership behaviors and organizational commitment and between organizational commitment and job satisfaction and performance", Leadership and organizational Development Journal, Vol.30 No.1, pp, 53-86.

Lee, P.C.B. (2000), "Turnover of information technology professionals: a contextual model", Accounting, Management and Information Technology, Vol. 10, pp. 101-124.

Lee, T.W., \&Mowday, R.T. (1987), "Voluntarily Leaving an Organization: an empirical investigation of Steers and Mowday's model of turnover", Academy of Management Journal, Vol. 30, pp 721-743.

Lee, T.W., and Mitchell, T.R. (1994), "An alternative approach: the unfolding model of voluntary employee turnover", Academy of Management Review; Vol. 19, pp. 51-89.

Locke, E.A. (1976), "The nature and causes of job satisfaction", Handbook of Industrial and Organizational Psychology, Rand McNally, Chicago, IL, pp.1297-349.

Lok Peter and Crawford John (1999), "The relationship between commitment and organizational culture, subculture, leadership style and job satisfaction in organizational change and development", Leadership \& Organization Development Journal,vol ;20/7,pp; 365-373

Lund, Daulatram B (2003), "Organizational Culture and Job Satisfaction", Journal of Business and Industrial Marketing Vol. 18 No.3, pp.219-236.

McMillan, A.C., "A configuration framework for diversity: socialization and culture", Personnel Review, Vol. 34 No4, pp. 488-503.

Mackenzie, K.D. (1986), Organizational Design: The organizational audit and analysis technology, Norwood, NJ: Ablex Publishing Corporation.

Maertz, C.P., Jr., \& Campion, M.A. (1998). "25 years of voluntary turnover research: A review and critique. In C.L. Cooper, \& I.T. Roberttson (Eds.)", International Review of Industrial and Organizational Psychology, Vol.3, pp. 49-81. NY: Willey.

Martin, J. (1992), Cultures in Three Organizations: Three Perspectives. London: Oxford University Press.

Mary, J. H. (1993). "The dynamics of organizational culture", Academy of Management Review, Vol.18 No.3, pp. 657-693.

Mehdi, M., Elham, M.Y., Tahereh., D.R. (2010). "The Relationship between Faculty Members perception of The Organizational Culture Types and Their Preferences for Instruction and Teaching in Iranian College of Education and Psychology", Procedia Social \& Behavioral Sciences, Vol.5, pp. 1841-1848.

Miseung Shim (2010), "Factors influencing child welfare employee's turnover: Focusing on organizational culture and climate", Children and Youth Service Review. V32, pp. 847-56.

Murphy, K.R. and Cleveland, J,N (1995), "Understanding Performance Appraisl: Social, Organization, and Goal-based Perspectives", Sage Publications, Thousand Oaks, CA.

Nystrom., P.C (1993), "Organizational cultures, strategies and commitments in health care organizations", Health Care Management Review, Vol.18, page.43-109.

Nazim Ali (2010), "Factors affecting overall job satisfaction, and turnover intention”, Journal of Managerial Sciences, Vol. 2, No. 2 pp. 239-252.

O Reilly, C.A. III, Chatman, J.A., and Caldwell, D.F. (1991). "People and organizational culture: A profile comparison approach to assessing Person-Organization fit", Academy of Management Journal, Vol. 34, pp. 487-516. 
Odom, R.Y., Boxx,W.R., Dunn, M.G. (1990), "Organizational cultures, commitment, satisfaction and cohesion", Public Productivity and Management Review, Vol.14, pp.157-169.

Ogbonna, E. and Harris, L.C. (2000), "Leadership style, organizational culture and performance: empirical evidence from the UK companies", InternationalJournal of Human Resource Management, Vol.11, No.4. pp 766-788.

Organ, D.W. (1988), "Organizational Citizenship Behavior: The good soldier syndrome”, The Lexington, MA: Lexington Books.

Parker, C.P., Baltes, B.B., Young, S.A., Huff, J.W., Altmann, R.A., Lacost, H.A., et al, (2003), "Relationship between psychological climate perceptions and work outcomes: a meta-analytic review", Journal of Organizational Behavior, Vol. 24, pp. 389-416.

Pennie G .Foster-Fishman and Christopher B. Keys, (1997), "The Person/Environment Dynamics of Employee Environment: An organizational Culture Analysis", American Journal of Community Psychology Vol. 25 No.3, pp.345-369.

Pettigrew, A.M. (1979), "On studying Organizational Culture”, Administrative Sciences Quarterly, Vol.24, pp. 570-81.

Price, J. L. (1977), The study of Turnover. Ames: Iowa State University Press.

Quinn, R.E., (1988), Beyond Rational Management, San Francisco: JosseyBass.

Robbins, S.P. (2003), Organizational behavior: Concepts, Controversies, and Applications, $10^{\text {th }}$ Ed, Prentice Hall, Upper Saddle River, NJ.

R.L., Tung \& Alain Verbeke (2010), "Beyond Hofstede and Globe: Improving the quality of cross cultural research" Journal of International business Studies, Vol. 41, pp. 1259-1274.

Rotundo, M., \&Sackett, P.R., (2002), "The relative importance of task, citizenship, and counterproductive performance: A policy capturing approach", Journal of Applied Psychology, Vol. 87, pp. 66-80.

Saeed, T., Tayyab, B., Haque, A., Ahmad, H., and Chaudhry, A., (2010), "Knowledge Management Practices: Role of Organizational Culture", ASBBS Annual Conference: Los Vegas, Vol.17, No.1, pp.1027-1036)

Schein.E.H. (1991).The role of the founder in the creation of organizational culture. In P.J Forest, L.F. Moore, M.R. Louis, C.C. Lundberg, and J. Martin (Eds.), reframing organizational culture (pp. 14-25). Beverly Hills, CA: Sage.

Seashore, S., Lawler, E., Mirvis, P. and Cammann, C. (1982), Observing and Measuring Organizational Change: A Guide to Field Practice, Willey, New York, NY.
Sheridan, J.E (1992), "Organizational Culture and Employee Retention", Academy of Management Journal, Vol.35, pp. 1036-56.

Slater, S.F., \&Narver, J.C. (1994), "Does competitive environment moderate the market orientation-performance relationship?" Journal of Marketing, Vol.58, pp.46-55.

Stone, D.L., Stone-Romero, E.F., and Lukaszewski, K.M (2007), “The impact of cultural values on the acceptance and effectiveness of human resource management policies and practices", Human Resource Management Review, Vol.17, pp.152-165.

Smith, C.A., Organ, D.W. and Near, J.P (1983), “Organizational Citizenship Behavior: Its nature and antecedents", Journal of Applied Psychology, Vol.68, pp. 653-63.

Song, J.H., Kim, H.M., and Kolb, J.A., "The effects of learning organization culture on the relationship between Interpersonal trust and organizational commitment”, Human Resource Development Quarterly, Vol.20 No.2, pp; $147-167$.

SoumenduBiswas and Arup Verma (2007), "Psychological Climate and Individual Performance in India: Test of a Mediated Model”, Employee Relations, Vol.29, No.6, pp. 664-676.

Stefanie, K.J., Courtney, L.H., and Miguel, A.Q., (2009), “Organizational citizenship behaviors in performance evaluations: Distributive justice or injustice”, J Bus Psychol, Vol.24, pp-409-418.

Su-Chao, C.,\& Lee, M.S., (2007), “A study on relationship among leadership, organizational culture, the operation of learning organization and employee's job satisfaction", The Learning Organization, Vol.14, No.2, pp.155-185.

Tsui, A.S., Wang, H, and Xing, K.R. (2011), "Organizational culture in China, an analysis of culture dimensions and culture types",Management and Organization Review, Vol.2, No. 3 pp, 245-376.

Watrous, K.M., Huffman, A.H., and Pritchard, R.D., "When coworkers and managers quit: the effects of turnover and shared values on performance", Journal of Business and Psychology, Vol.21 No.1, pp.103-126.

Williams, L.J and Anderson, S.E (1991), "Job Satisfaction and Organizational Commitment as predictors of organizational citizenship and in-role behaviors", Journal of Management, Vol.17, No.3, pp. 601-17.

Woodard, G., Cassill, N., \& Herr, D. (1994), "The relationship between psychological climate and work motivation in retail environment", New York, NY: Routledge. 